\title{
GOVERNOR AND PRESIDENT
}

Mr. Ronald Reagan seems bent on validating the predictions of those among his political opponents who were saying, only a few weeks ago, that he could not fail to be a bad governor of California. In retrospect, possibly when it comes time to stand again for election in 1970, he may reflect that it was foolish to have brought the differences between himself and others on the administration of the University of California so crudely to a head. It may now seem smart to have organized the dismissal of the president of the state university within three weeks of taking office, but a few years from now, when the governor will be a little more used to the exhilaration of power, it will not seem particularly remarkable to him that a man with the right to appoint to the Board of Regents should also have power over those the regents appoint. With luck, he may by then appreciate that it is a good deal easier to do serious damage to intellectual institutions such as universities than to work improvements on them. But Mr. Reagan has not lacked good advice, only the sense to listen to it.

It is, of course, too soon to know what will be the effects of Mr. Reagan's brashness on the welfare of the great university over which political chance has given him authority, but it is important to be clear why his doings in the past few days are reprehensible. The dispute about tuition fees at the University of California, important though it may be, is not the central issue. Whether the time has come in California for the state university to follow the precedent of most others in the United States (Nature, 213, 222; 1967) and to ask its students to pay tuition fees is necessarily a difficult question, with a case to be made on each side. The hard core of Mr. Reagan's offence is that he has forced his own view on the University of California in such a way as to make it plain that he is insensitive to the need that universities-wherever they areshould enjoy a real measure of independence in the running of their affairs. To scorn this principle is an assault on civil liberty as real as to suppose that newspapers can be censored with impunity, or judges bribed. And if Dr. Kerr has been sacked because he was stubborn about tuition fees, who can be sure that his successor will not be sent packing on some issue bearing even more directly on the right of the university to determine what to teach, and how.

The next few weeks will be important. The first rumblings from the campus at Berkeley suggest that the sacking of Dr. Kerr may canalize the formidable energies of the student body there away from the exotic causes which have in the past caused the new governor such pain into a protest against this affront to the independence of the university. Rough justice, some will say. But in the long-term interests of the university, an early return to near normality would be best. The governor himself could do a lot to help, chiefly by providing some tangible assurance that the sacking of Dr. Kerr is not-as some speeches during his election would suggest - the first move in a serious assault on the university. Much, of course, will depend on the new president, whoever he will be. If Mr. Reagan has learned anything from his first blunder, it should be that the new man should be known to be at least as staunch a defender of academic freedom as Dr. Kerr. To appoint a yesman may seem politically expedient, but it would be disastrous for the university. Before the staff and students go cheerfully back to work, they have every reason to ask for assurance on this point. It would also be reasonable to ask for a clearer definition of the way in which the Board of Regents is empowered to act. If, as it should, the board can hire and fire the president of the university, it cannot also be empowered to initiate and to implement new policies without making each difference of opinion with the president, however legitimate, seem an occasion for dismissal. The ideal would be some real separation between the academic administration of the university and the making of political decisions about the scale on which it should be supported from public funds. Unfortunately, to judge from what Mr. Reagan has been saying, there is a danger that the politicians will seek an even firmer grip on what happens at the university.

And what is at stake? Mr. Reagan's previous career as a film star may not have equipped him to appreciate how critically the intellectual well-being of a university depends on the sense of freedom which peoplestudents as well as staff-enjoy. Certainly he cannot have realized that the capacity of his university to attract talented recruits from all over the worldnot just the United States-is a simple proof of the esteem in which the university is held. His first duty is naturally to the taxpayers of California, but it is unthinkable that they would wish him to cause irreparable damage to an institution which is even more widely admired than their climate. And it is also, of course, unthinkable that all of them can be as indifferent as Mr. Reagan seems to be to the benefits which society derives from independent universities.

\section{ALSO IN BRITAIN}

There is an ironic echo of what has been happening in California in the special report on Parliament and Control of University Expenditure by the Public Accounts Committee of the House of Commons 